\title{
Phytoestrogen content of subterranean clover related to ewe growth and reproduction*
}

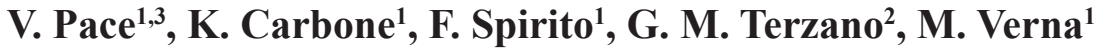 \\ and D. Settineri ${ }^{1}$
}

\author{
${ }^{1}$ Department of Animal Feeding and Nutrition, \\ ${ }^{2}$ Department of Animal Reproduction, \\ Istituto Sperimentale per la Zootecnia \\ Via Salaria, 31-00016, Monterotondo (Roma), Italy
}

\begin{abstract}
24 Comisana ewes were fed on subterranean clover (SC, phytoestrogen content $=0.794$ $\mathrm{mg} / \mathrm{g}$ of DM) or Italian ryegrass (IR) for one year to verify the effects of a prolonged ingestion of phytoestrogens on growth rate and reproduction. The animal initial weights were: $\mathrm{SC}=25.3$ $\mathrm{kg} \pm 2.99$ and $\mathrm{IR}=24.7 \mathrm{~kg} \pm 3.83$, respectively. Differences on growth became evident after one month of feeding; after 170 days ewe weights were $47.5 \pm 3.43$ vs $41.1 \pm 4.35 \mathrm{~kg}(\mathrm{P} \leq 0.01)$ and ADG was $145.5 \mathrm{~g} / \mathrm{d}$ vs $107.2 \mathrm{~g} / \mathrm{d}(\mathrm{P} \leq 0.001)$. No differences were recorded on the onset of puberty and on lamb births: 14 for SC group (LW=4.83 kg) and 15 for IR $(4.36 \mathrm{~kg})$.
\end{abstract}

KEY WORDS: ewes, phytoestrogens, growth, reproduction

\section{INTRODUCTION}

The phytoestrogens detectable in subterranean clover are well-known for their detrimental effects on fertility and reproduction of ruminants due to the presence of a considerable amount of formononetin and its highly oestrogenic rumen metabolite equol. In a previous experiment some new lines of subterranean clover, selected for their very low content of fomononetin (less than the $1 \%$ of total phytoestrogens), did not show any influence on fertility and fecundity of sheep fed, for about two months, on fresh subterranean clover, but caused a consistent increase of growth (Pace et al., 2000).

\footnotetext{
* Supported by the Italian Ministry of Agriculture

${ }^{3}$ Corresponding author: e-mail: vilma.pace@isz.it
} 
We aimed to investigate the long term effects of estrogenic isoflavone administration on growth rate, fertility and reproduction of young ewes.

\section{MATERIAL AND METHODS}

The trial was carried out on two groups of 12 Comisana ewes fed on subterranean clover ( $\mathrm{SC}$ phytoestrogen content $=0.794 \mathrm{mg} / \mathrm{g}$ of dry matter, $\mathrm{DM}$ ) or Italian ryegrass (IR) for about one year; forages were offered ad libitum, avoiding refusal, as fresh herbage (cut off and weighed every day) for about two months and later as hay; the diets were integrated with adequate amounts of maize grains $(300 \mathrm{~g} / \mathrm{d}, 88 \% \mathrm{DM}, 10 \% \mathrm{CP}, 1.25 \mathrm{MFU} / \mathrm{kg} \mathrm{DM})$ and sunflower meals to result iso-energetic and iso-proteic (Table 1). Two groups of animals with similar weights were formed (ILW: $\mathrm{SC}=25 \pm 3$ and $\mathrm{IR}=25 \pm 4 \mathrm{~kg}$ ) and the growing period lasted about 170 days. The chemical composition of forages (Table 1) and the phytoestrogen content of SC (by HPLC, Table 2; Pace et al., 2000) were determined every 15 days starting when the plants were $15 \mathrm{~cm}$ tall.

Ewes were weighed every two weeks and bled weekly by jugular puncture; after 135 days of feeding two rams were introduced in each group. Endovaginal eco-graphies were done monthly to control the reproductive apparatus and pregnancy trends. Plasma samples were used for phytoestrogen and its metabolite content (HPLC) and for progesterone (P4) assays (DSL-3900 P4 RIA Kit; sensitivity $=0.03 \mathrm{ng} / \mathrm{ml}$ ). The ewes were considered to have attained puberty when $\mathrm{P} 4$ plasma levels became higher than $1.0 \mathrm{ng} / \mathrm{ml}$. The lambing dates were used to calculate the breeding times with an assumed gestation length of $150 \mathrm{~d}$.

Variance analysis of data was performed by the following statistical models: $\mathrm{y}=\mu+\mathrm{A}_{\mathrm{i}}+\varepsilon_{\mathrm{ij}}$ and $\mathrm{y}=\mu+\mathrm{A}_{\mathrm{i}}+\mathrm{B}_{\mathrm{j}+}(\mathrm{A} * \mathrm{~B})_{\mathrm{ij}+} \varepsilon_{\mathrm{ijk}}$, where $\mathrm{A}=$ feeding groups (i: 1 and 2 ) and $\mathrm{B}=\operatorname{sexes}(\mathrm{j}: 1$ and 2); means were compared by Student $t$-test.

Table 1. Average chemical composition (means \pm s.d. of 5 determinations, $\%$ on DM), average nutritive values (MFU, $\mathrm{kg} / \mathrm{DM}$ ) and average daily DM intakes (dI, $\mathrm{kg}$ ) of subterranean clover (SC) and ryegrass (IR)

\begin{tabular}{lcrrrrrc}
\hline Forages & DM $60^{\circ} \mathrm{C}$ & \multicolumn{1}{c}{ CRP } & \multicolumn{1}{c}{ Ash } & NDF & ADF & MFU & dI \\
\hline SC $^{1}$ & $19 \pm 6$ & $17 \pm 4$ & $10 \pm 1$ & $30 \pm 8$ & $23 \pm 5$ & 0.76 & 0.65 \\
IR $^{2}$ & $27 \pm 3$ & $11 \pm 3$ & $9 \pm 1$ & $47 \pm 5$ & $29 \pm 4$ & 0.82 & 0.55 \\
SC hay $^{3}$ & $87 \pm 3$ & $10 \pm 2$ & $11 \pm 1$ & $39 \pm 3$ & $32 \pm 1$ & 0.67 & 0.65 \\
IR hay $^{4}$ & $89 \pm 2$ & $7 \pm 2$ & $8 \pm 1$ & $70 \pm 5$ & $45 \pm 5$ & 0.74 & 0.60 \\
\hline
\end{tabular}

supplemented with sunflower meals: ${ }^{1} 250 \mathrm{~g} / \mathrm{d}, 86 \% \mathrm{DM}, 20 \% \mathrm{CP}, 0.70 \mathrm{MFU} / \mathrm{kg} \mathrm{DM} ;{ }^{2,3} 300 \mathrm{~g} / \mathrm{d}, 90 \%$ DM, 34\% CP, $0.85 \mathrm{MFU} ;{ }^{4} 350 \mathrm{~g} / \mathrm{d}, 90 \% \mathrm{D}$ M, 34\% CP, $0.85 \mathrm{MFU}$

daily CP and MFU of complete diets: ${ }^{1} 178 \mathrm{~g}, 0.98 ;{ }^{2} 176 \mathrm{~g}, 1.01 ;{ }^{3} 179 \mathrm{~g}, 1.00 ;{ }^{4} 175 \mathrm{~g}, 1.04$ 


\section{RESULTS AND DISCUSSION}

The average phytoestrogen content of fresh SC was very close to that of SC hay (Table 2). The average ratios of formononetin/genistein $(\mathrm{F} / \mathrm{G})$ were quite low: these data are relevant as formononetin is the compound which exerts the deleterious oestrogenic effect previously attributed to SC (Adam, 1995).

Table 2. Average phytoestrogen concentrations of SC fresh herbage and hay (means \pm s.d.) and ratio between formononetin and genistein $(\mathrm{F} / \mathrm{G})$

\begin{tabular}{lccccc}
\hline & \multicolumn{5}{c}{ Phytoestrogen content, $\mathrm{mg} / \mathrm{g}$ on $\mathrm{DM}$} \\
\cline { 2 - 6 } Forages & total & genistein & biochanin A & formononetin & $\mathrm{F} / \mathrm{G}$ \\
\hline SC & $0.79 \pm \_0.14$ & $0.71 \pm 0.14$ & $0.02 \pm 0.01$ & $0.03 \pm 0.02$ & 0.04 \\
SC hay & $0.82 \pm \_0.11$ & $0.78 \pm \_0.10$ & $0.01 \pm 0.01$ & $0.02 \pm \_0.01$ & 0.02 \\
\hline
\end{tabular}

No undegraded phytoestrogens were detected in plasma samples at any time; the only detected metabolite was the p-ethyl phenol with amounts ranging from $11.1 \pm 2$ to $2.1 \pm 1 \mu \mathrm{g} / \mathrm{ml}$ depending on elapsed time from the meal.

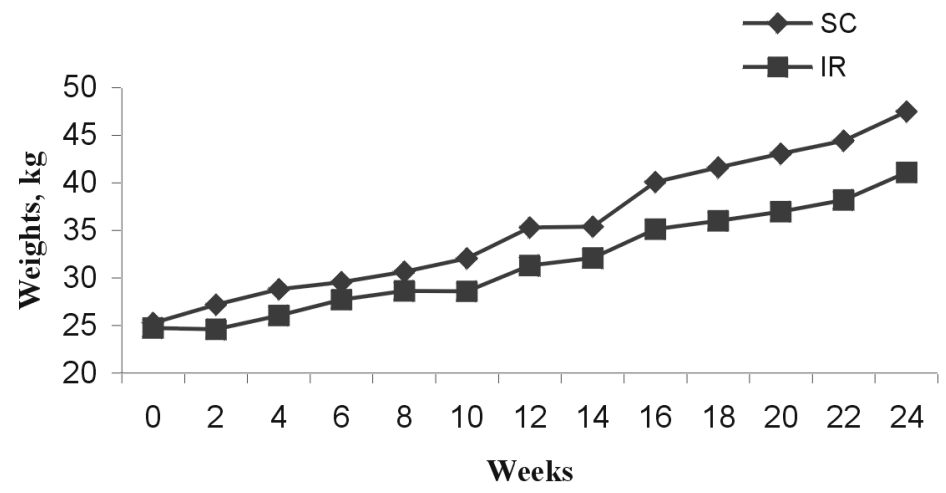

Figure 1.Weight trends during the growing period of ewes fed on clover (SC) and ryegrass (IR)

The differences in weights, always higher in SC group, became statistically significant after about two months of feeding (Figure 1; $\mathrm{SC}=32.1^{\mathrm{a}}$ and $\mathrm{IR}=28.6^{\mathrm{b}}$ $\mathrm{kg} ; \mathrm{P} \leq 0.05)$; at the end of the growing period, weights of $\mathrm{SC}$ group resulted $9.7 \%$ higher than IR group $\left(\mathrm{SC}=45.5^{\mathrm{A}}\right.$ and $\mathrm{IR}=41.1^{\mathrm{B}} \mathrm{kg}$; $\left.\mathrm{P} \leq 0.001\right)$; moreover the $\mathrm{ADG}$ resulted $26.3 \%$ higher for the ewes fed on SC compared to those fed on IR and the liveweight at puberty (Table 3) was $5.3 \mathrm{~kg}$ higher in SC group (11.8\%). These results were in agreement with the studies of other researchers (Adlercreutz, 1998; Ososki and Kennelly, 2003) about the ability of oestrogenic isoflavones to influence the metabolism and biosynthesis of several compounds and tissues, passing through cell membranes and interacting with enzymes and receptors. 
Table 3. Average daily gains during growing period (g/d, 170 days), weights (kg) and ages (days) at puberty and ages at conceiving time of SC and IR groups of ewes

\begin{tabular}{lccccc}
\hline Groups & $\mathrm{N}$ & ADG & Weights $^{1}$ & Ages $^{1}$ & Ages $^{2}$ \\
\hline SC & 12 & $145.5^{\mathrm{A}}$ & $44.9^{\mathrm{a}}$ & 216.1 & 235.1 \\
$\mathrm{IR}$ & 12 & $107.2^{\mathrm{B}}$ & $39.6^{\mathrm{b}}$ & 219.9 & 236.1 \\
& & & & \\
Mean & 24 & 126.4 & 42.3 & 218.0 & 235.6 \\
RMSE $^{3}$ & & 23.7 & 4.18 & 14.69 & 11.86 \\
\hline
\end{tabular}

${ }^{1}$ at the first P4 plasma level $>1.0 \mathrm{ng} / \mathrm{ml} ;{ }^{2}$ conceiving age; ${ }^{3}$ Root Mean Square Error;

${ }^{\mathrm{a}, \mathrm{b}}$ significantly different for $\mathrm{P} \leq 0.05 ;^{\mathrm{A}, \mathrm{B}}$ significantly different for $\mathrm{P} \leq 0.001$

No abnormalities on the reproductive apparatus were noted by endovaginal eco-graphies. No significant differences were observed with respect to lamb births and weights; all ewes became pregnant, two with twins on SC and three with twins on IR. The ages at puberty and at conceiving time, as well as the lambing data, show the absence of all the detrimental effects of SC on the ovarian function and fertility previously reported by several authors since 1940s (Adam et al., 1990; Adam, 1995) for formononetin-rich lines of this forage. This suggests that, if formononetin level is less than $0.1 \%$ of DM, a prolonged ingestion of $\mathrm{SC}$, containing proportional amounts of genistein and biochanin, do not produce neither infertility nor reproductive disorders.

\section{CONCLUSIONS}

The presence of oestrogenic isoflavones in the diet of young ewes, at amounts detectable in new lines of SC (low formononetin, medium genistein and biochanin) seems to improve growth rate and liveweight without detrimental effects on animal reproductive performance. Further researchs is needed to confirm the positive effect of phytoestrogen containing clover on growth of ruminants and monogastrics and to clarify their action at molecular and cellular level.

\section{REFERENCES}

Adams N.R., 1990. Permanent infertility in ewes exposed to plant oestrogens. Aust. Vet. J. 67, 197-205

Adams N.R., 1995. Detection of the effects of phytoestrogens on sheep and cattle. J. Anim. Sci. 73, 15091515

Adlercreutz H., 1998. Evolution, nutrition, intestinal micro flora and prevention of cancer: a hypothesis. Proc. Soc. Exp. Biol. Med. 217, 241-246

Ososki A.L., Kennelly E.J., 2003. Phytoestrogens: a review of the present state of research. Phytother. Res. 17, 845-869

Pace V., Settineri D., Rassu S.P.G., 2000. Effect of subterranean clover administration on the growth and reproduction of sarda ewes. $1^{\text {st }}$ Note. Proceeding of the XXXV International Symposium of the Società Italiana di Zootecnia, Ragusa (Italy), pp. 257-265 